\title{
Triple Helix: How the Model Affects Small Medium-Sized Enterprises
}

\author{
Somariah Fitriani ${ }^{1 \mathrm{a})}$, Sintha Wahjusaputri ${ }^{1)}$, Ahmad Diponegoro ${ }^{1)}$ \\ ${ }^{1}$ Department of Educational Administration, University of Muhammadiyah Prof. DR. HAMKA, Jakarta, 12790, Indonesia
}

a)Corresponding author: somariah@uhamka.ac.id

\begin{abstract}
A Cross-sector collaboration among university, government, and industry/business in the context of the Triple Helix model has become the central issue of addressing the growth of the global economy, particularly, Small and Medium-Sized Enterprises (SMEs). Thus, the purpose of this study was to examine the effect of three leading actors in the Triple Helix model to the development of SMEs. The study employed a quantitative approach and Structural Equitation Model (SEM) to find out the effects of three helixes on SMEs. 246 respondents of SMEs from two regions; the province of Bandung and Banten took part in an online survey. The findings reported that the government, industry, and government affect positively to small and medium-sized enterprises. It indicates that the Triple Helix model plays a significant contribution to SMEs.
\end{abstract}

Keywords: triple helix model; small and medium-sized enterprises; entrepreneurship; creative industry.

\section{INTRODUCTION}

The Triple Helix model is fast becoming a key instrument in the economic advances of a region. The interaction of three helixes, namely university, government, and industry/business in the Triple Helix model can create innovation and constitute a basic foundation of economic development, which is particularly recognized through entrepreneurship developed in small and medium-sized enterprises (SMEs). As a part of the creative industry, SMEs bring about positive outlooks both in developing and developed countries. For instance, in German and other European countries, SMEs are well-thought-out to the backbone of the nation and provide local economies for 99 percent of private-sector commercial [1]-[3]. Thurik even highlighted that entrepreneurship developed in SMEs is the engine of the nation's economic growth [4]. In African countries, SMEs become the key instrument of socio-economic development and poverty reduction
[5] as well as have a significant contribution to the Gross Domestic Product of Nigeria from 1982-2012 [6]. In the words of Carpentier, Landveld, and Shahiar, SMEs are estimated to provide 600 million new occupations by the year of 2030 in other developing countries and sub-Saharan Africa [7].

As a developing country, Indonesian MSMEs supply $60 \%$ of the Gross Domestic Product (GDP), provides $89 \%$ of private-sector employment, and make up $99 \%$ for all companies. Despite facing much potential economic turmoil, GDP growth remains strong for 2018 to 2019 at a forecast of 5.3 percent, but still below the 7 percent target [8]. The Central Statistical Bureau reported that Indonesia's economy grew by 5.7 percent in the quarter I-2019, reaching IDR 3782.4 trillion [9]. Agreeing with these statements, Padachi and Bhiwajee pointed out that not only do SMEs contribute to poverty alleviation, but they also provide employment and source of livelihood for millions of people across the world [10]. Karaev, Koh, and Szamosi have noted two challenges encountered by SMEs in the face of the 
current global business competition such as the ASEAN economic community. The first challenge is they need to respond to business opportunities, which due to globalization is widely accessible. In the second one, to develop their business, they should create and keep up business networks. If they do not respond immediately to challenges, the performance, the activity, and the sustainability of SMEs will be hindered [11]. Under these circumstances, the Triple Helix model, which is firstly coined by Etzkowitz \& Leydesdorff [12] is recognized as providing social and economic benefits especially when three helixes are collaborating on innovation infrastructure [13].

Previous studies have found that the triple helix idea provides advantages in different forms of collaboration [14]-[16] since their collaboration produces a knowledge sharing that leads to innovation [17]. Therefore, the collaboration between universities, private corporations, and government bodies is highly essential in the development of SMEs in order to increase economic growth, social welfare, and competitiveness. As Rostek argued that, for small and medium-sized companies to succeed in a changing environment and strong business competition [18], they need to boost their profitability as their competitiveness often improves their negotiating position in a business competition [19]. To fill this study's void, this study explores the impact of three helixes on the growth of small and medium-sized enterprises as an innovative industry to support them in a competitive era.

\section{METHODS}

Participants: 246 SMEs situated in the province of Bandung and the regency of Serang, Pandeglang, and Tangerang Selatan, Banten participated in the research. The regions are the representatives of the West Java population and Banten population in Indonesia. Bandung has been well known as a creative city since it has a numerous of SMEs, whereas Tangerang Selatan is famous for its name, "The city of lifestyle gateway" since it is closed to Jakarta, the capital city of Indonesia, which has four functions: a residential city, merchant city, education city, and service city. Besides, Tangerang Selatan has a large number of SMEs account for 23.781 in 2018. However, Serang and Pandeglang, which were included in the research, just took a small part of the sample. The characteristics of the sample include gender, age, level of education, length of business, business turnover, business assets, kinds of business, and kinds of ownership as presented in detail in table 1 .

TABLE 1. Demographic Characteristics of the Sample

\begin{tabular}{|c|c|c|c|}
\hline Characteristics & Description & Number & Percentage \\
\hline \multirow{3}{*}{ Gender } & Male & 103 & 41.87 \\
\hline & Female & 141 & 57.32 \\
\hline & Unknown & 2 & 0.81 \\
\hline \multirow[t]{4}{*}{ Age } & 21-40 years old & 73 & 29.67 \\
\hline & 41- 60 years old & 67 & 27.24 \\
\hline & $61-70$ years old & 23 & 9.35 \\
\hline & Unknown & 83 & 33.74 \\
\hline \multirow{6}{*}{ Level of education } & Elementary school & 1 & 0.40 \\
\hline & Junior high school & 3 & 1.22 \\
\hline & Senior high school & 75 & 30.49 \\
\hline & The diploma I/II/III & 10 & 4.07 \\
\hline & Undergraduate & 153 & 62.19 \\
\hline & Graduate & 4 & 1.63 \\
\hline \multirow[t]{4}{*}{ The length of business } & $1-5$ years & 63 & 25.61 \\
\hline & $6-10$ years & 79 & 32.12 \\
\hline & $11-15$ years & 43 & 17.47 \\
\hline & More than 15 years & 61 & 24.80 \\
\hline \multirow[t]{4}{*}{ Business turnover } & Less than 50 million rupiahs & 20 & 8.13 \\
\hline & 50- 300 million rupiahs & 94 & 38.21 \\
\hline & $>300-2.5$ billion rupiahs & 118 & 47.97 \\
\hline & $>2.5-50$ billion rupiahs & 14 & 5.69 \\
\hline \multirow[t]{3}{*}{ Business assets } & Less than 50 million rupiahs & 31 & 12.61 \\
\hline & $50-500$ million rupiahs & 155 & 63 \\
\hline & $>500$ million -10 billion rupiahs & 60 & 24.39 \\
\hline \multirow[t]{2}{*}{ Kinds of business } & Culinary & 79 & 32.12 \\
\hline & Crafts & 50 & 20.33 \\
\hline
\end{tabular}




\begin{tabular}{llcc}
\hline & Fashion & 64 & 26.01 \\
& Mixed business (culinary + craft) & 44 & 17.88 \\
Kinds of ownership & Other & 9 & 3.66 \\
& Family business & 20 & 8.14 \\
& Individual business & 223 & 90.65 \\
& Franchise & 1 & 0.40 \\
& Other partnership & 2 & 0.81 \\
\hline
\end{tabular}

Research Design: The study emphasizes examining the effects of three cross-sector collaborators of the Triple Helix model, university, industry, and government to the growth of SMEs in two provinces; Bandung and Banten in Indonesia. Thus, the study employed Structural Equitation Modeling (SEM) by using Lisrel as a part of the quantitative approach. The participants must respond to the items by using a 5point, Likert scale ranging from (1) strongly disagree to (5) strongly agree to 11 items of University, 12 items of Government, and 11 items of industry.

Procedures: The data were collected through a faceto-face survey during Focus Group Discussion (FGD) conducted on 21 October 2019 in Bandung, online survey, and telephone calls. For the 20 participants of FGD, they received tumblers with the logo of our university. The participants of FGD, then, assisted us to share the questionnaire through WhatsApp social media to their community. We also contacted SMEs to fill the questionnaire through WhatsApp since we got the catalog containing the information about SMEs from the personnel staff of the Department of cooperatives, small and medium businesses of Tangerang Selatan. For SMEs in Serang and Pandeglang, in addition to making a phone call to them, we made contact with them via WhatsApp as well.

\section{RESULTS AND DISCUSSION}

Based on the analysis of using a histogram, the questionnaire has 24 outlier data that must be removed to produce a good and valid analysis. So, the net data used for this study is 222 data.

\subsection{Reliability of data}

This study used the Cronbach's Alpha coefficient of at least 0.5 . If the value is above 0.5 , then the question items in the questionnaire are reliable. The items in the questionnaire for university, government, and industry variables are reliable, which has a Cronbach's Alpha value $>=0.5$ as seen in the below table

TABLE 2. Reliability of data

\begin{tabular}{ccc}
\hline \multicolumn{3}{c}{ Reliability Statistics } \\
\hline Variable & Cronbach's & N of Items \\
& Alpha & \\
University & .990 & 11 \\
Government & .899 & 12 \\
Industry & .965 & 11 \\
\hline
\end{tabular}

\subsection{Test for Composite Variables}

The next step is to re-do the descriptive analysis of data that does not involve outlier data and deleted variables. The following are findings based on the analysis of each composite variable.

TABLE 3. The results of the composite variable test on the university variable Statistics

\begin{tabular}{|c|c|c|c|c|c|c|c|c|c|c|c|}
\hline & A1 & A2 & A3 & A4 & A5 & A6 & A7 & A8 & A9 & A10 & A11 \\
\hline $\begin{array}{ll}\mathrm{N} & \text { Valid }\end{array}$ & 222 & 222 & 222 & 222 & 222 & 222 & 222 & 222 & 222 & 222 & 222 \\
\hline Missing & 0 & 0 & 0 & 0 & 0 & 0 & 0 & 0 & 0 & 0 & 0 \\
\hline Mean & 2.5180 & 2.8108 & 2.4910 & 2.9009 & 2.7523 & 2.7613 & 2.6622 & 2.4099 & 2.7252 & 2.7432 & 2.6757 \\
\hline $\begin{array}{l}\text { Std. } \\
\text { Deviation }\end{array}$ & 1.13247 & 1.32168 & 1.09603 & 1.42349 & 1.28580 & 1.28399 & 1.23241 & 1.15280 & 1.27673 & 1.26985 & 1.22317 \\
\hline Variance & 1.282 & 1.747 & 1.201 & 2.026 & 1.653 & 1.649 & 1.519 & 1.329 & 1.630 & 1.613 & 1.496 \\
\hline Skewness & .370 & .033 & .429 & .053 & .060 & .015 & .170 & .651 & .080 & .052 & .133 \\
\hline $\begin{array}{l}\text { Std. Error of } \\
\text { Skewness }\end{array}$ & .163 & .163 & .163 & .163 & .163 & .163 & .163 & .163 & .163 & .163 & .163 \\
\hline Kurtosis & -.738 & -1.433 & -.440 & -1.500 & -1.396 & -1.450 & -1.238 & -.434 & -1.381 & -1.323 & -1.155 \\
\hline $\begin{array}{l}\text { Std. Error of } \\
\text { Kurtosis }\end{array}$ & .325 & .325 & .325 & .325 & .325 & .325 & .325 & .325 & .325 & .325 & .325 \\
\hline
\end{tabular}


TABLE 4. The results of the composite variable test on the government variable

\begin{tabular}{|c|c|c|c|c|c|c|c|c|c|c|c|c|c|}
\hline \\
\hline & & G1 & G2 & G3 & G4 & G5 & G6 & G7 & G8 & G9 & G10 & G11 & G12 \\
\hline \multirow[t]{2}{*}{$\mathrm{N}$} & Valid & 222 & 222 & 222 & 222 & 222 & 222 & 222 & 222 & 222 & 222 & 222 & 222 \\
\hline & Missing & 0 & 0 & 0 & 0 & 0 & 0 & 0 & 0 & 0 & 0 & 0 & 0 \\
\hline \multicolumn{2}{|c|}{ Mean } & 3.8514 & 4.1892 & 4.4595 & 3.9189 & 3.9099 & 4.5450 & 3.8919 & 4.5631 & 4.0495 & 3.9910 & 4.1216 & 4.0405 \\
\hline \multicolumn{2}{|c|}{ Std. Deviation } & .65941 & .55492 & .62791 & .50581 & .52191 & .49909 & .72263 & .51501 & .39485 & .41457 & .39059 & .41811 \\
\hline \multicolumn{2}{|c|}{ Variance } & .435 & .308 & .394 & .256 & .272 & .249 & .522 & .265 & .156 & .172 & .153 & .175 \\
\hline \multicolumn{2}{|c|}{ Skewness } & -.309 & -.752 & -1.284 & -1.204 & -1.078 & -.182 & .166 & -.456 & -.011 & -1.216 & 1.096 & -.107 \\
\hline \multicolumn{2}{|c|}{$\begin{array}{l}\text { Std. Error of } \\
\text { Skewness }\end{array}$} & .163 & .163 & .163 & .163 & .163 & .163 & .163 & .163 & .163 & .163 & .163 & .163 \\
\hline \multicolumn{2}{|c|}{ Kurtosis } & .318 & 3.940 & 2.992 & 4.395 & 3.661 & -1.985 & -1.067 & -1.328 & 5.858 & 8.497 & 2.353 & 4.702 \\
\hline \multicolumn{2}{|c|}{$\begin{array}{l}\text { Std. Error of } \\
\text { Kurtosis }\end{array}$} & .325 & .325 & .325 & .325 & .325 & .325 & .325 & .325 & .325 & .325 & .325 & .325 \\
\hline
\end{tabular}

TABLE 5. The results of the composite variable test on the industry variable

Statistics

\begin{tabular}{|c|c|c|c|c|c|c|c|c|c|c|c|}
\hline & I1 & I2 & I3 & I4 & 15 & I6 & 17 & 18 & 19 & I10 & I11 \\
\hline $\begin{array}{l}\text { Valid } \\
\end{array}$ & 222 & 222 & 222 & 222 & 222 & 222 & 222 & 222 & 222 & 222 & 222 \\
\hline Missing & 0 & 0 & 0 & 0 & 0 & 0 & 0 & 0 & 0 & 0 & 0 \\
\hline Mean & 3.8153 & 3.8694 & 3.5450 & 4.0946 & 3.8468 & 3.8514 & 3.3559 & 3.8694 & 3.7252 & 3.8288 & 3.5000 \\
\hline Std. Deviation & .67075 & .64243 & .74618 & .72140 & .62668 & .63849 & .85323 & .67002 & .68016 & .63636 & .78878 \\
\hline Variance & .450 & .413 & .557 & .520 & 393 & .408 & .728 & . 449 & .463 & .405 & .622 \\
\hline Skewness & -2.035 & -2.458 & -.749 & -1.895 & -2.548 & -2.387 & -.491 & -2.211 & -1.772 & -2.391 & -.698 \\
\hline $\begin{array}{l}\text { Std. Error of } \\
\text { Skewness }\end{array}$ & .163 & .163 & .163 & .163 & .163 & .163 & .163 & .163 & 163 & .163 & 163 \\
\hline Kurtosis & 6.308 & 8.723 & 1.678 & 6.877 & 9.123 & 8.430 & .031 & 7.310 & 4.719 & 8.177 & 1.029 \\
\hline $\begin{array}{l}\text { Std. Error of } \\
\text { Kurtosis }\end{array}$ & .325 & .325 & .325 & .325 & .325 & .325 & .325 & .325 & .325 & .325 & .325 \\
\hline
\end{tabular}

Based on the analysis of each composite variable as shown in Table 3. 4 and 5, it concluded that 1) The standard error value, which is seen from the standard error of skewness and the standard error of kurtosis, on the university, government, and industry variables are very small, which is below 1 . So that it can be said that the entire sample can accurately represent the entire population; 2) in the standard deviation and variance values, the university variable shows the value above 1 . This indicates that data variations are too high, whereas the Government and industry variables show a value below 1, which indicates that data variation is not too high; 3) In kurtosis values, it is known that there is no frequency in one class that is very extreme when compared to the frequency in other classes. The ideal kurtosis value is under 3 , then the university variable has reached the ideal kurtosis value, while the Government and industry variables do not reach the ideal kurtosis value; 4) The data is declared normally distributed when the skewness value is in the range of values from -2 to 2 . Thus, the data on all variables are normally distributed.

\subsection{The analysis of Structural Equation Modeling (SEM)}

a. The hypothesis

Hypothesis 1: University variable has a positive effect on the government on the development of SMEs

Hypothesis 2: University variable has a positive effect on the industry on the development of SMEs Hypothesis 3: Industry variable has a positive effect on the government on the development of SMEs

b. Initial Measurement (Measurement Model)

The initial measurement phase aims to determine the value of error variance, $t$-value, and Standardized Loading Factor (SLF) and processed with Lisrel 8 software. In this section, the Confirmatory Factor Analysis (CFA) method is used to evaluate each variable that has a question 
item, which is really appropriate. Here are the results of running from the Lisrel software.

TABLE 6. Threshold 1

\begin{tabular}{|l|l|}
\hline \multicolumn{2}{|l|}{ Threshold 1: } \\
\hline Error variance & all + \\
\hline SLF & $>=0.5$ \\
\hline & $>=$ \\
t-value & 2.75 \\
\hline
\end{tabular}

It is concluded that in the iteration 1 running of CFA results, the error variance, t-value, and SLF values have fulfilled the specified criteria (see Threshold 1 table). Then the model is valid so that it can proceed to the next stage.

c. Test Validity and Reliability of SEM

This stage tests the validity and reliability of each question item. The validity test aims to see the accuracy of the question items for each variable. The reliability test is then performed to determine the consistency of measurement of the constituent question items. In this study, the reliability test was carried out using Construct Reliability (CR). CR can be calculated with the following formula.

$$
C R=\frac{(\Sigma \mathrm{SLF})^{2}}{(\Sigma \mathrm{SLF})^{2}+\Sigma e_{j}}
$$

The value of $e_{j}$ is obtained from the results of running, namely the error variance of each question item. The standard CR value used in this study is > $=0.7$. The following results of $\mathrm{CR}$ presented as follows: university is 0.99 , government is 0.97 , and industry is 0.98 . Based on the results, it indicated that all $\mathrm{CR}$ values above meet the $\mathrm{CR}$ standard values per variable.

d. Structural Test Model

At this stage, the overall model test is conducted to find out whether the overall model is fit or not. Testing the whole model uses criteria from the goodness of fit index and t-value $(>=$ $2.75)$. If the test scores meet the cut off values of each criterion, then the whole model is said to be fit. Here are the results of the goodness of fit for the structural model test.

TABLE 7. The Results of the goodness of fit for the structural model test

\begin{tabular}{|c|l|c|c|l|}
\hline No. & Goodness of fit & Cut-off value & Value & Remark \\
\hline \multicolumn{5}{|c|}{ Absolute fit indices } \\
\hline 1 & RMR & $<=0.10$ & 0.049 & Fit \\
\hline \multicolumn{5}{|c|}{ Incremental fit indices } \\
\hline 2 & CFI & $>=0.9$ & 0.95 & Fit \\
\hline 3 & IFI & $>=0.9$ & 0.95 & Fit \\
\hline \multicolumn{5}{|c|}{ Parsimony fit indices } \\
\hline 4 & PNFI & $0.60-0.90$ & 0.88 & Fit \\
\hline 5 & PGFI & $0.50-1.00$ & 0.57 & Fit \\
\hline
\end{tabular}

\begin{tabular}{|l|l|r|l|}
\hline Hypothesis & \multicolumn{1}{|c|}{ Path } & \multicolumn{1}{c|}{ t-value } & \multicolumn{1}{|c|}{ Remark } \\
\hline H1 & A - G & 5.63 & Accepted \\
\hline H2 & A - I & 6.41 & Accepted \\
\hline H3 & I - G & 9.12 & Accepted \\
\hline
\end{tabular}

Based on the table above, all hypotheses are accepted, namely, the three variables have a positive influence on the development of creative SMEs. Below figures 2 and 3 are Lisrel running results about Measurement Model Test (t-value Structural Model Test (t-value). 


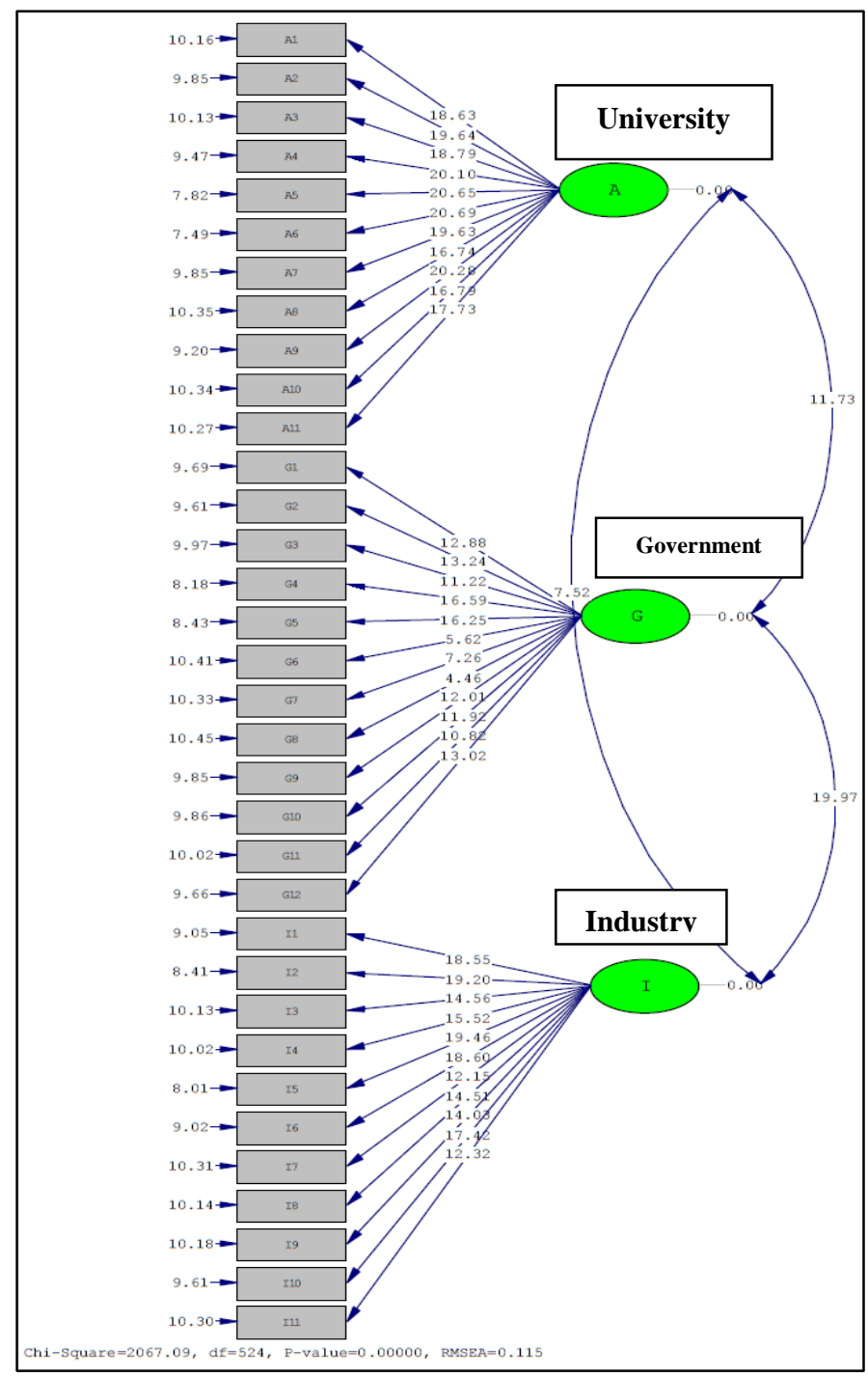

FIGURE 1. The Result of Measurement Model Test (t-value)

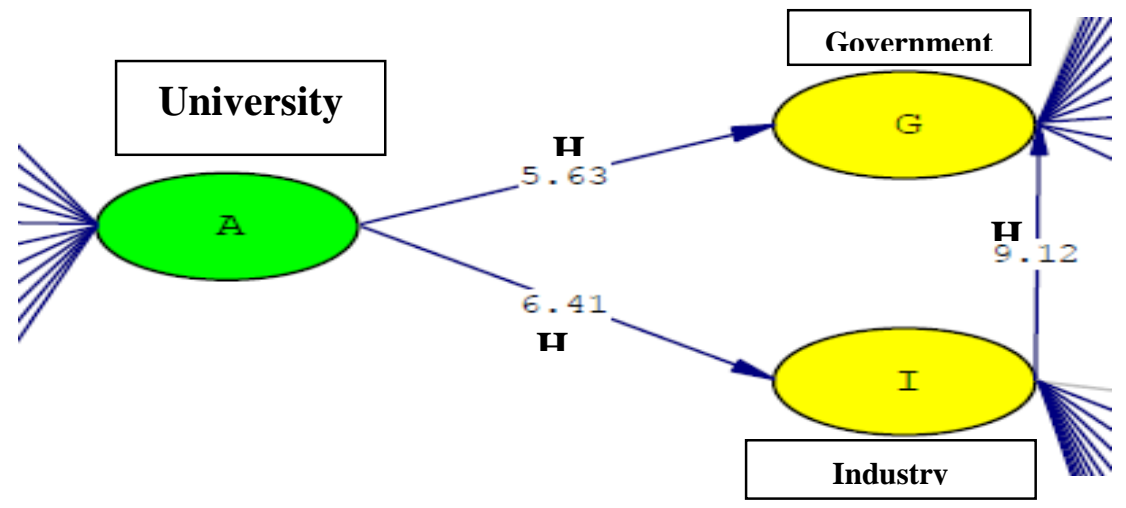

FIGURE 2. Structural Model Test (t-value)

The hypothesis of this study has been proven that three helixes; namely University, Government, and
Industry affected positively to the development of small and medium-sized enterprises. This finding is similar to 
other studies conducted by Brink and Madsen, and Ueasangkomsate and Jangkot, which found out that the Triple Helix-related partnership between SMEs and the industrial sector and government has a positive effect. This partnership has improved creativity, efficiency, innovation, and the performance for SMEs [20], [21], while at the same time, the partnership also demonstrates potential benefits for SMEs in emerging economies in working with Triple Helix Agents to boost their success in innovation. Their involvement leads to and supports both triple helix and SMEs [20]. According to Etzkowitz, such experiences of interaction improve the conditions for development in knowledge-based societies and also become a catalyst for innovation as they contribute to the conversion of science and technology into economic progress [22]. Pugh found that since Devolution, Triple Helix strategies have been prominently featured with mixed success in Welsh development strategy and programs [23]. Nevertheless, Pugh also criticized the government, which focused too heavily on universities as drivers of innovation and economic development at the expense of business, especially in a weaker region. In addition to the positive effect of Triple Helix collaboration, Wang highlights some of the limitations and flaws of the universityindustry-academy and presents the evolutionary path to Triple Helix of university-industry-government collaboration and development to address these practical and theoretical challenges [24].

Nata'rio, Couto, Almeida also revealed the presence of a positive relationship between the dynamics of the triple helix model in terms of the different types and objectives to be innovated that is concerning the introduction of new products as well as ecological innovation and their efforts to develop communication about the barriers to innovation - obviously, the lack of information and the geographical site, the corporations' innovation performance and the level of cooperation and interaction with the university giving them benefits in obtaining additional financial resources and prestige for the researcher, as well as in obtaining information for the process of education [25].

The concept of the Triple Helix model has been employed in various countries as an organizational technique for regional development, for instance, in Sweden [26] and Ethiopia to further the knowledgebased economy [27]. In Brazil, the Triple Helix has become a university-based "movement" to generate incubators [28]. In Indonesia, the cluster method is one of the innovation-based business incubation practices in an incubator that has also been implemented in many countries. The aim of the business clustering method enables the delivery of cheaper and better resources to industry, LEs, universities, and other developmentsupporting organizations [29]. Tambunan also identified that clustering benefits SME growth and rural development in Indonesia, as the majority of SMEs are located in rural areas. Since the interactions between Triple Helix actors, such as higher education institutions (HEIs), businesses, and government agencies, are at the root of innovation and are a fundamental premise of economic development [23], [30]. The collaboration of three leading players needs to be intensified and must be designed in a systematic scheme to avoid the confusion of SMEs. Based on the research findings and discussion, it indicates that the collaboration of university, government, and industry/business has affected the SMEs' performance and innovation and brings a significant impact but with some limitations and barriers, which are required to be evaluated.

\section{CONCLUSIONS}

The findings have revealed the positive impacts of Triple Helix collaboration in Indonesia, particularly to the development of small and Medium-sized enterprises, which enable them to produce creativity and innovation of their products and their sustainability. With the assistance of three helixes in terms of cross-sector collaboration, SMEs can survive and improve performance and produce better and more innovative products. Thus, this study highlights the significance of the implementation of the Triple Helix model in any collaboration, particularly among three leading sectors for regional development and economic welfare of society and to promote the knowledge-based economy.

\section{ACKNOWLEDGMENTS}

DRPM, the Ministry of Research and Higher Education financially funded the research of the decentralization scheme of PDUPT. We sincerely feel thankful to the Institute of Research and Development (Lemlitbang) of the University of Muhammadiyah Prof. DR. HAMKA, which supports the research

\section{REFERENCES}

[1] H. Herr and Z. M. Nettekoven, The Role of Small and Medium-sized Enterprises in Development: What Can be Learned from the German Experience? Department for Asia and the Pacific Hiroshimastra ße, 2017.

[2] P. Wymenga, V. Spanikova, J. Derbyshire, and A. Barker, "Are EU SMEs recovering? Annual Report on EU SMEs 2010/2011 for the European Commission," 2011.

[3] ECORYS, "EU SMEs in 2012 at the crossroads. Annual report on small and medium-sized enterprises in the EU.," 2012.

[4] R. Thurik and S. Wennekers, "Entrepreneurship, small business and economic growth," J. Small Bus. 
Enterp. Dev., vol. 11, no. 1, pp. 140-149, 2004

[5] Z. O. Opafunso and A. O. Omoseni, "The Impact of small and medium scale enterprises on economic development of Ekiti State, Nigeria," J. Econ. Sustain. Dev., vol. 5, no. 16, 2014.

[6] O. T. Okhankhuele, "Effect of small and medium scale enterprises on economic growth in Nigeria.," $J$. Res. Natl. Dev., vol. 15, no. 1, 2017.

[7] C. L. Carpentier, R. Landveld, and N. Shahiar, "Role of MSMES and entrepreneurship in achieving the SDGS," ICSB supported by OSITA ABANA, UNCTAD NEW YORK OFFICE, 2019. [Online]. Available: https://icsb.org/wpcontent/uploads/2019/09/Gazette-Sep.-9.pdf. [Accessed: 24-Sep-2019].

[8] Asian Development Bank, Asian development outlook (ADO) 2018: How technology affects jobs. Metro Manila, Philippines: Asian Development Bank, 2018.

[9] Badan Pusat Statistik., "Ekonomi Indonesia Triwulan I 2019 Tumbuh 5, 07 Persen.," 2019. [Online]. Available:

https://www.bps.go.id/pressrelease/2019/05/06/1620/ ekonomi-indonesia-triwulan-i-2019-tumbuh-5-07persen.html. [Accessed: 07-Jun-2019].

[10] K. Padachi and S. Lukea Bhiwajee, "Barriers to employee training in small and medium sized enterprises: Insights and evidences from Mauritius," Eur. J. Train. Dev., vol. 40, no. 4, pp. 232-247, 2016.

[11] A. Karaev, S. C. Lenny Koh, and L. T. Szamosi, "The cluster approach and SME competitiveness: a review.," J. Manuf. Technol. Manag., vol. 18, no. 7, pp. 818-835, 2007.

[12] H. Etzkowitz and L. Leydesdorff, "The Triple Helix: University - Industry - Government Relations: A Laboratory for Knowledge-Based Economic

[21] P. Ueasangkomsate and A. Jangkot, "Enhancing the innovation of small and medium enterprises in food manufacturing through Triple Helix Agents," Kasetsart J. Soc. Sci., vol. XXX, pp. 1-9, 2017.

[22] H. Etzkowitz, "The Triple Helix of university industry - government relations: Implications for Policy and Evaluation," Stockholm, SE-114 28, 2002.

[23] R. Pugh, "The good, the bad and the ugly: Triple helix policies and programmes in Wales," 2014.

[24] C. Wang, "From the triple felix of universityindustry-academy to the triple helix of universityindustry-government in China," J. Knowledge-based Innov. China, vol. 4, no. 3, pp. 152-162, 2012.

[25] M. M. Natário, J. P. A. Couto, and C. F. R. de Almeida, "The triple helix model and dynamics of innovation: a case study," Jpurnal Knowledge-based Innov. China, vol. 4, no. 1, pp. 36-54, 2012.

[26] M. Jacob, "Utilization of social science knowledge in
Development.," EASST Rev. 14, vol. 14, pp. 14-19, 1995.

[13] N. Yokakul and G. Zawdie, "The knowledge sphere, social capital and growth of indigenous knowledgebased SMEs in the Thai dessert industry," Sci. Public Policy, vol. 38, no. 1, pp. 19-29, 2011.

[14] H. Etzkowitz, "The entrepreneurial university wave: from ivory tower to global economic engine," Ind. High. Educ., vol. 28, no. 4, pp. 223-232, 2014.

[15] H. Etzkowitz and R. Viale, "Polyvalent knowledge and the entrepreneurial university: a third academic revolution?," Crit. Sociol., vol. 36, no. 4, pp. 595$609,2010$.

[16] L. Leydesdorff, "The triple helix quadruple helix, an $\mathrm{N}$-tuple helices: explanatory models for analysing the knowledge-based economy?," J. Knowl. Econ., vol. 3, pp. 25-35, 2012.

[17] S. Herliana, "Regional innovation cluster for small and medium enterprises (SME): A triple helix concept," Procedia-Social Behav. Sci., vol. 169, pp. 151-160, 2015.

[18] K. M. Rostek, "The reference model of competitiveness factors for SME medical sector.," Econ. Model., vol. 29, no. 5, pp. 2039-2048, 2012.

[19] E. Ada, Y. Kazancoglu, and M. Sagnak, "Improving competitiveness of small and medium-sized enterprises (SMEs) in agriproduct export business through ANP: The Turkey case.," Agribusiness, vol. 29, no. 4, pp. 524-537, 2013.

[20] T. Brink and S. O. Madsen, "The triple helix frame for small- and medium-sized enterprises for innovation and development of offshore wind energy," A J. Univ. Innov. Entrep., vol. 3, no. 4, pp. $1-23,2016$

science policy: Systems of Innovation, Triple Helix and VINNOVA," Soc. Sci. Inf., vol. 45, no. 3, pp. 431-462, 2006

[27] M. Saad, G. Zawdie, and C. Malairaja, "The triple helix strategy for universities in developing countries: The experiences in Malaysia and Algeria," Sci. Public Policy, vol. 35, no. 6, pp. 431-443, 2008.

[28] M. Almeida, "The evolution of the incubator movement in Brazil," Int. J. Technol. Glob., vol. 1, no. 2, pp. 258-277., 2005.

[29] T. T. H. Tambunan, "Promoting small and medium enterprises with a clustering approach: A policy experience from Indonesia," J. Small Bus. Manag., vol. 43, no. 2, pp. 138-154., 2005.

[30] J. Dzisah and H. Etzkowitz, "Triple helix circulation: The heart of innovation and development," Int. J. Technol. Manag. Sustain. Dev., vol. 7, no. 2, pp. 101$115,2008$. 